\title{
Groundwater and Solute Budget (A Case Study from Sabkha Matti, Saudi Arabia)
}

\author{
Waleed Saeed ${ }^{1, *} \mathbb{0}$, Orfan Shouakar-Stash ${ }^{1,2,3}{ }^{\mathbb{C}}$, Warren Wood ${ }^{4}$, Beth Parker ${ }^{3}(\mathbb{C}$ \\ and André Unger 1 \\ 1 Department of Earth and Environmental Science, University of Waterloo, Waterloo, ON N2L 3G1, Canada; \\ orfan@uwaterloo.ca (O.S.-S.); andre.unger@uwaterloo.ca (A.U.) \\ 2 Isotope Tracer Technologies Inc., Waterloo, ON N2V 1Z5, Canada \\ 3 School of Engineering, University of Guelph, Guelph, ON N1G 2W2, Canada; bparker@uoguelph.ca \\ 4 Department of Earth and Environmental Sciences, Michigan State University, 288 Farm Lane, \\ East Lansing, MI 48824, USA; wwwood@msu.edu \\ * Correspondence: wsaeed@uwaterloo.ca; Tel.: +1-519-500-9078
}

Received: 11 November 2020; Accepted: 30 November 2020; Published: 3 December 2020

\begin{abstract}
Sabkha Matti is the largest inland sabkha $\left(2950 \mathrm{~km}^{2}\right)$ in the Arabian Peninsula. The drainage area supporting this sabkha is $>250,000 \mathrm{~km}^{2}$ and is the discharge point for part of the ten thousand meter thick regional groundwater systems ranging in age from Precambrian through Miocene in the Rub' al Khali structural basin. A hydrologic budget was constructed for this sabkha, where water fluxes were calculated on the basis of hydraulic gradient and conductivities measured in both shallow and deep wells. The evaporation rates from the surface of the sabkha were estimated from the published data and indicate that almost all the annual rainfall is lost by surface evaporation. The water flux multiplied by its solute concentration showed that nearly all the solutes in the sabkha were derived by upward leakage from the underlying regional aquifers rather than the weathering of the aquifer framework, from precipitation, or from other sources. Steady-state estimates within a rectilinear control volume of the sabkha indicate that about $1 \mathrm{~m}^{3} /$ year of water enters by lateral groundwater flow, $2 \mathrm{~m}^{3} /$ year of water exits by lateral groundwater flow, $20 \mathrm{~m}^{3} /$ year enters by upward leakage, $780 \mathrm{~m}^{3} /$ year enters by recharge from rainfall, and $780 \mathrm{~m}^{3} /$ year is lost by evaporation. The proposed conceptual model of the hydrology for sabkha Matti is assumed to apply to the rest of the inland sabkhas of the Arabia Peninsula and to many ancient environments of deposition observed in the geologic record.
\end{abstract}

Keywords: Rub' al Khali; water budget; sabkha; solute budget; groundwater recharge

\section{Introduction}

Sabkha is an Arabic term that is widely used for a salt flat. Evaporation greater than precipitation and a source of solutes are the main requirements for the occurrence of this phenomenon. Sabkhat (plural of Sabkha) are characterized by flat landscapes, shallow groundwater levels (usually less than one meter), and high water salinities. In the Arabian Peninsula, there are two types of sabkhat: coastal and inland. Coastal sabkhat are marginal marine areas [1,2]. In contrast, inland sabkhat are found in basins, away from the coast, and typically surrounded by sand dunes [3]. The formation of both coastal and inland sabkhat are explained by the evaporation of continental groundwaters through the surface, which produces brines and subsequently causes the precipitation of evaporite minerals [1]. Thus, the inland sabkha systems are important in water resource assessments owing to the fact that they represent discharge points of local and regional groundwater systems. In certain large, closed basins, such as the Caspian Sea in Eurasia, the Great Salt Lake in North America, Lake Eyre in Australia, 
Lake Titicaca in South America, and Lake Chad in Africa, surface water rather than groundwater dominates the solute input.

The Rub' al Khali (RAK) structural basin lies below the largest sand desert in the world. The structural basin covered an area of approximately $560,000 \mathrm{~km}^{2}$ and is bound by the Central Arabian Arch in the north, the Oman Thrust in the east, the Hadhramaut-Dhofar Arch in the south, and the Arabian Shield in the west (Figure 1a). Sabkha Matti (SM) is a flat salt covered portion of the sabkha Matti drainage basin $\left(>250,000 \mathrm{~km}^{2}\right)$ that is located in the Ar Rub al Kali desert and is underlain by the larger Ar Rub al Kali structural basin (Figure 1a,b). SM extends about $150 \mathrm{~km}$ south from the western Abu Dhabi coastline and across the border between the United Arab Emirates and Saudi Arabia [4]. At the coast of Abu Dhabi, SM is characterized by a narrow strip of supratidal carbonate sands and evaporites that form a coastal sabkha. Southward, it grades into an area of inland siliciclastic sediments. The conceptual model for the origin of solutes in the coastal sabkha is the ascending brine model given by [1]. That is, the origin and evolution of solutes and mineral precipitation involves: (1) the upward leakage of brines from the regional aquifers that underlay the sabkha, (2) deflation that removes sand down to the level of the water table, and (3) extensive evaporation that causes the formation of a halite crust and the accumulation of anhydrite and gypsum in the shallow subsurface. The question addressed in the current study is whether this ascending brine conceptual model is viable for the sabkha Matti inland sabkha. Thus, the aim of the current study is to quantitively estimate the water and solute fluxes to SM, which would ultimately lead to a better overall understanding of the regional hydrology in the Rub' al Khali structural basin and to investigate the role of SM in the regional hydrogeological system as a potential surface discharge point. It is assumed that the proposed conceptual model of the hydrology for sabkha Matti is applicable to the rest of the inland sabkhas of the Arabia Peninsula and to many ancient environments of deposition observed in the geologic record.

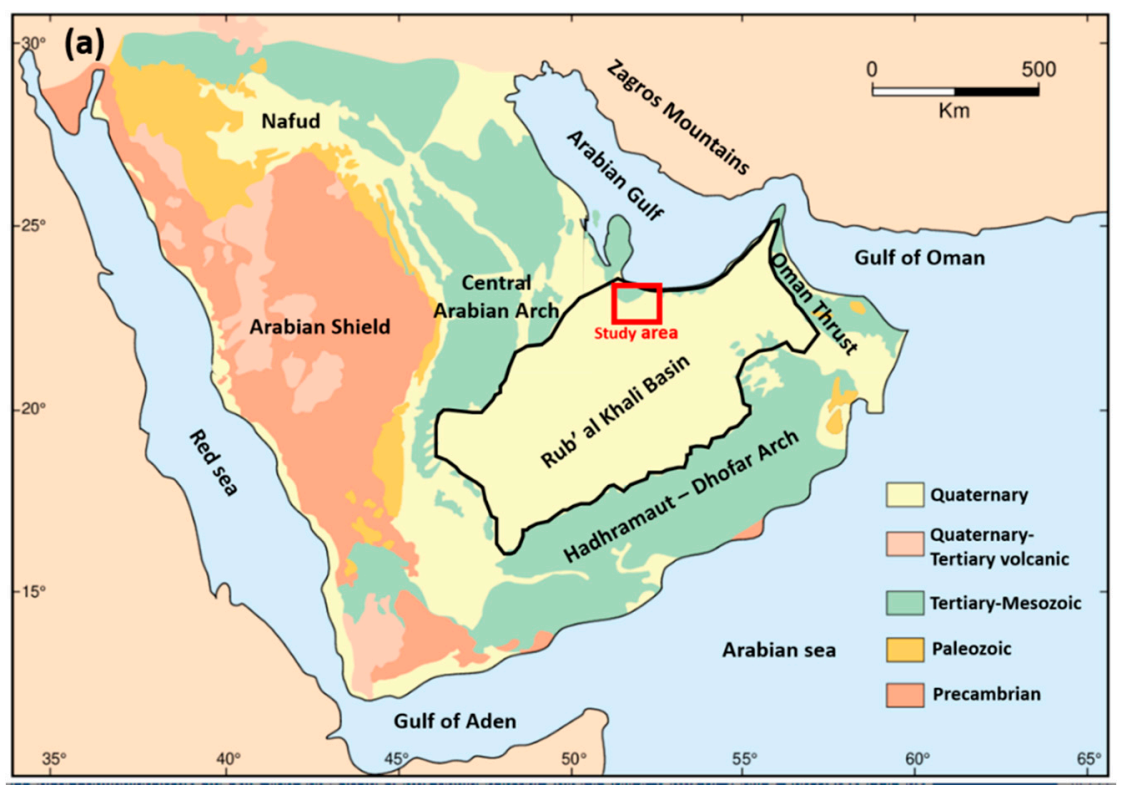

Figure 1. Cont. 


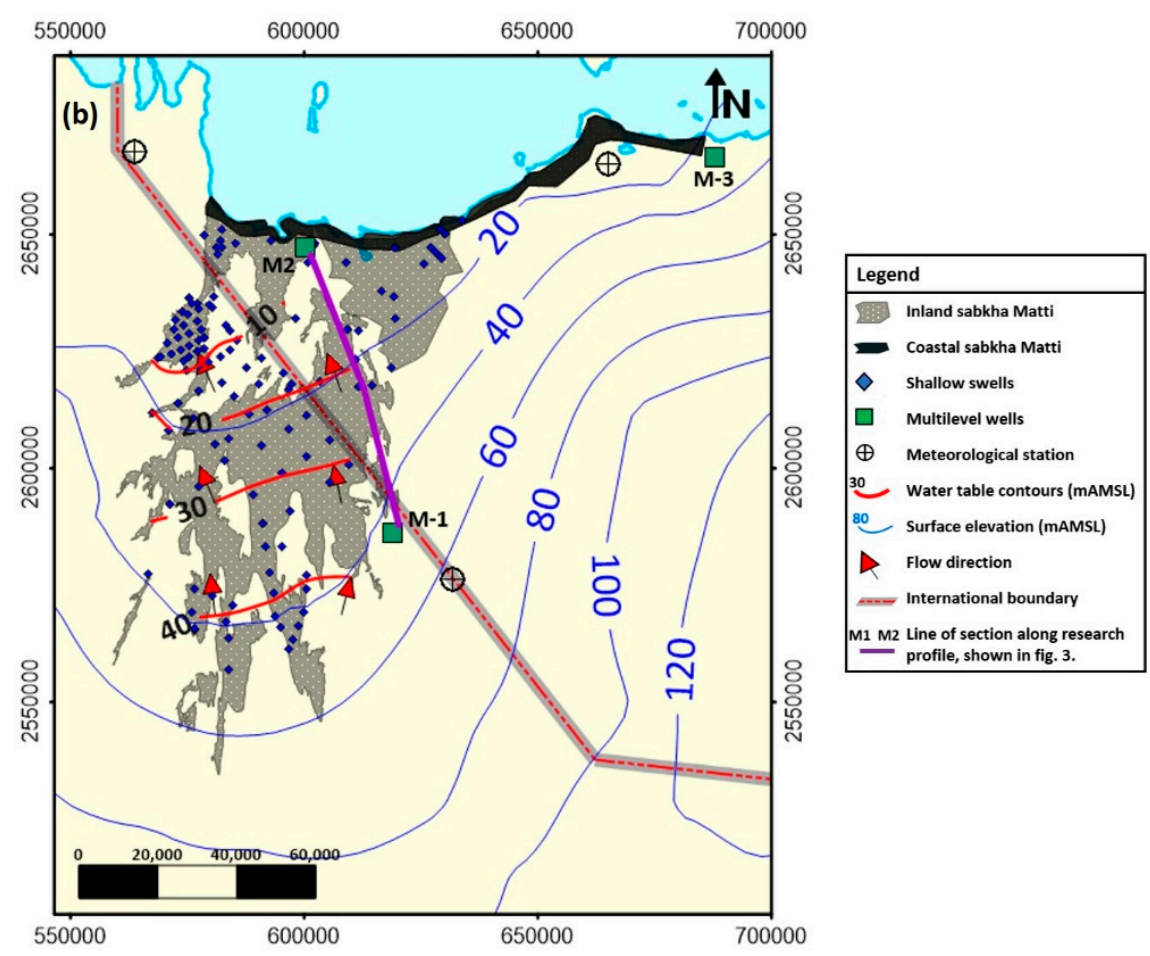

Figure 1. (a) Geologic sketch map of the Arabia Peninsula showing the location and boundaries of the Rub' al Khali structural basin (modified after [5]); (b) map showing the location of sabkha Matti, sampling locations, surface elevation, water level contours, and flow direction in the sabkha.

\section{Geological Setting}

The Matti sabkha is a wide, north-south trending, salt-covered area that extends about $150 \mathrm{~km}$ south from the western Abu Dhabi coastline and across the border between the United Arab Emirates and Saudi Arabia (Figure 1). It covers a portion of the sabkha Matti (SM) drainage basin $\left(>250,000 \mathrm{~km}^{2}\right)$ that is located in the Ar Rub al Kali desert and is underlain by the larger Ar Rub al Kali structural basin (Figure 1). The sabkha part of the larger drainage system is bound in the south by the sand dune system of the Rub' al Khali desert. The western and eastern boundaries of the sabkha are formed by the N-S linear margins of Neogene-age outcrops, known as Ras Musherib and Ras Mugherij, respectively [6]. A generalized W-E geologic cross section of the SM is shown in Figure 2. Beneath the sabkha lies a thick (6000-8000 m) Paleozoic-Cenozoic sedimentary sequence of carbonates, clastics, and evaporites that accumulated on the stable Arabian platform [7]. Above this sequence is a clastic deposit of Late Oligocene-Miocene age, known as the Hadrukh Formation. Following the deposition of the Hadrukh, the area now occupied by the Arabian Gulf area was subject to lagoonal-evaporitic deposition [8]. In this setting, marl, clay, dolomite, dolomitic limestone, anhydrite, and nodular gypsum of the Dam Formation were deposited [9]. In Mid-Miocene, the area was subject to gentle tilting and rapid erosion of the Arabian shield basement as a result of the Miocene-Pliocene uplift (Zagros Orogeny) [10]. This setting favored the deposition of continental clastic sediments of the Shuweihat Formation in fluvial, aeolian, and sabkha environments [11]. Since the Late Miocene-Pliocene, the Arabian Gulf foredeep basin has developed in front of the rising Zagros Mountains in response to a regional compressional event between the Arabian and Eurasian plates [12]. In the Late Quaternary, the region of SM was the site of drainage systems which derived fluvial sediments from rising mountains in western Saudi Arabia and Oman and deposited them into the Matti drainage basin [6]. Limited reworking and desiccation to these fluvial sediments occurred in the Mid-Holocene in response to rises in the groundwater table in response to the $\sim 140 \mathrm{~m}$ rise in the Arabian Gulf [1]. Subsequent deflation removed sands down to the level of the rising water table, causing the development of evaporite facies within the fluvial sands $[4,13]$. It is proposed that this fluvial sequence, within which the evaporite 
minerals have developed, be given the name sabkha Matti Formation (SMF) because of its extensive development. The SMF has an average thickness of about $5 \mathrm{~m}$, laterally continues by $50-80 \mathrm{~km} \mathrm{E}-\mathrm{W}$, and extends inland N-S from the Arabian coast for nearly $150 \mathrm{~km}$. The water table within the sabkha is less than $1 \mathrm{~m}$ below the land surface, which allows the evaporation of groundwater to occur directly from the water table.

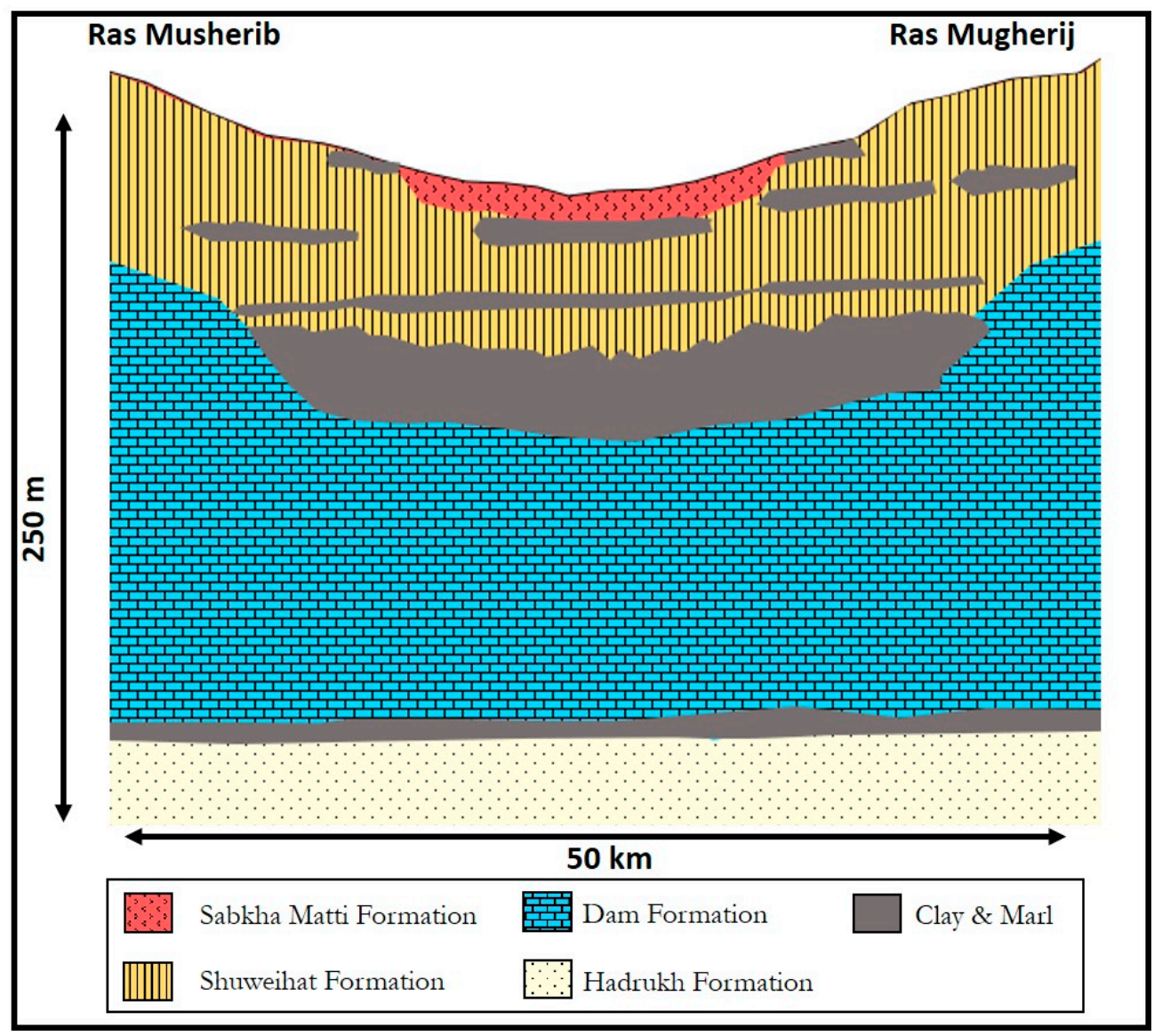

Figure 2. Generalized geologic cross section of the sabkha Matti from Ras Musherib in the west to Ras Mugherij in the east, as shown in Figure 1.

\section{Materials and Methods}

Figure 1 shows the location of the drilled holes in the study area. Within the border of Saudi Arabia, holes for 102 shallow piezometers $(<10 \mathrm{~m})$ were drilled between 1 and $2 \mathrm{~m}$ below the water table by using a Geoprobe, Model 6620DT, and a direct push machine. Nine piezometers of intermediate depth $(>10 \mathrm{~m}$ and $<25 \mathrm{~m}$ ) were drilled by a rotary drill rig (B53, manufactured by Mobile Drill Intl) mounted on a $4 \times 4$ truck. All the shallow and intermediate piezometers were constructed from a $50 \mathrm{~mm}$-diameter schedule 40 PVC pipe, slotted by a hacksaw on the bottom $1.5 \mathrm{~m}$ and covered with filter sock, with threaded joints containing couplings. The holes were backfilled with the loose sand collapsed around the piezometers. Within the border of Abu Dhabi, water samples were collected from eleven pre-existing monitoring wells. Details of the well construction data for these wells are reported in $[1,14,15]$. Water samples were collected using a dedicated plastic bailer. Three deep wells $(>100 \mathrm{~m})$ were drilled with rotary drills into the Dam and Hadrukh Formations. These wells were finished with 18 5/8 inch-diameter steel casings through the overburden sediments to the surface and were left as open bedrock borehole completions from the bottom of the casing to the remainder of the depth. Each of the three deep wells were provided with a cap, shut-off valve, and pressure gauge. All three deep wells were under flowing artesian conditions, which allowed the collection of water samples at the surface. For this study, five well cluster systems were drilled along a research profile, as shown in 
Figure 3. Each of the cluster wells was completed at different depths, and groundwater samples were collected from each aquifer individually to investigate any chemical variations between the aquifers. Analyses of all the water samples for the electrical conductivity (EC), $\mathrm{pH}$, temperature, and dissolved oxygen content were carried out in the field using a portable HQ40d meter (Hach Ltd., London, UK). Field measurements of alkalinity were made using a Hach field titration kit and expressed as the $\mathrm{mg} / \mathrm{L}$ of equivalent $\mathrm{HCO}_{3}$. All the water samples were filtered through $0.45 \mu \mathrm{m}$ filters and then acidified with double-distilled nitric acid for cation analysis and preserved unacidified for anion analysis. Analyses of major ions were performed by the ALS laboratory group, Waterloo, Canada. The analyses were carried out using ion chromatography in accordance with the protocol for analytical methods used by the Environmental Protection Act EPA 300.1 [16]. The analytical reproducibility and precision for each ion analysis were better than $5 \%$.

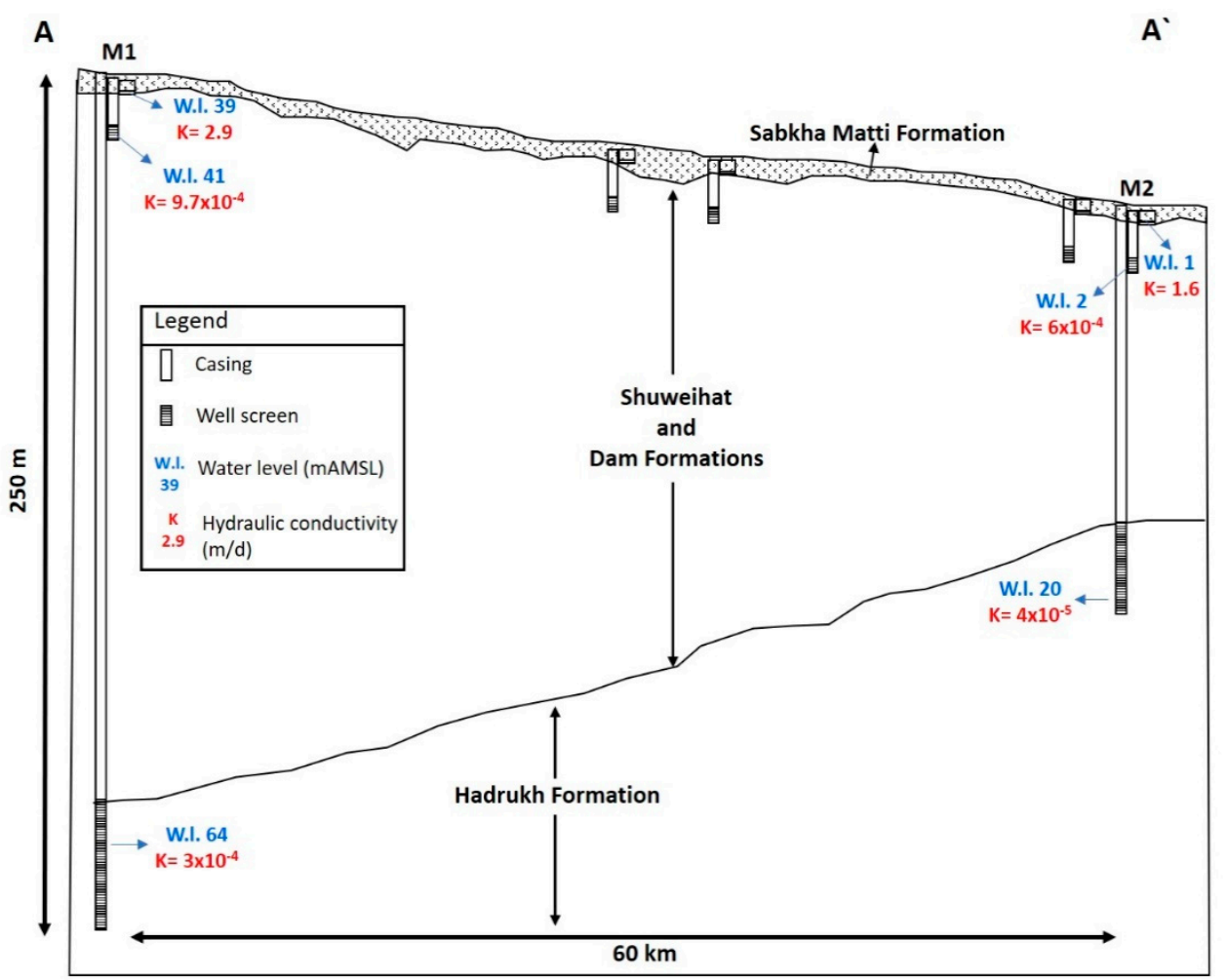

Figure 3. Transect M1-M2 showing multi-level observation wells that were installed in the sabkha Matti area. Trace of line of section is shown in Figure 1.

\section{Results}

\subsection{Hydrologic Budget}

A water budget for the SM was developed in order to understand the processes that control the hydrology of the sabkha and to quantify the individual components. The regional-scale system is assumed to operate under a steady-state flow condition, which means that all of the inflows to the sabkha must equal all of the outflows. The steady-state assumption is based on field observations, which confirm that the hydraulic heads throughout the sabkha area fluctuate very little over long time scales ( $>3$ years). The budget was developed around a representative control volume parallel to the groundwater flow direction of the sabkha that is $20 \mathrm{~km}$ long, $1 \mathrm{~m}$ wide, and $5 \mathrm{~m}$ deep (see Figure 4). 


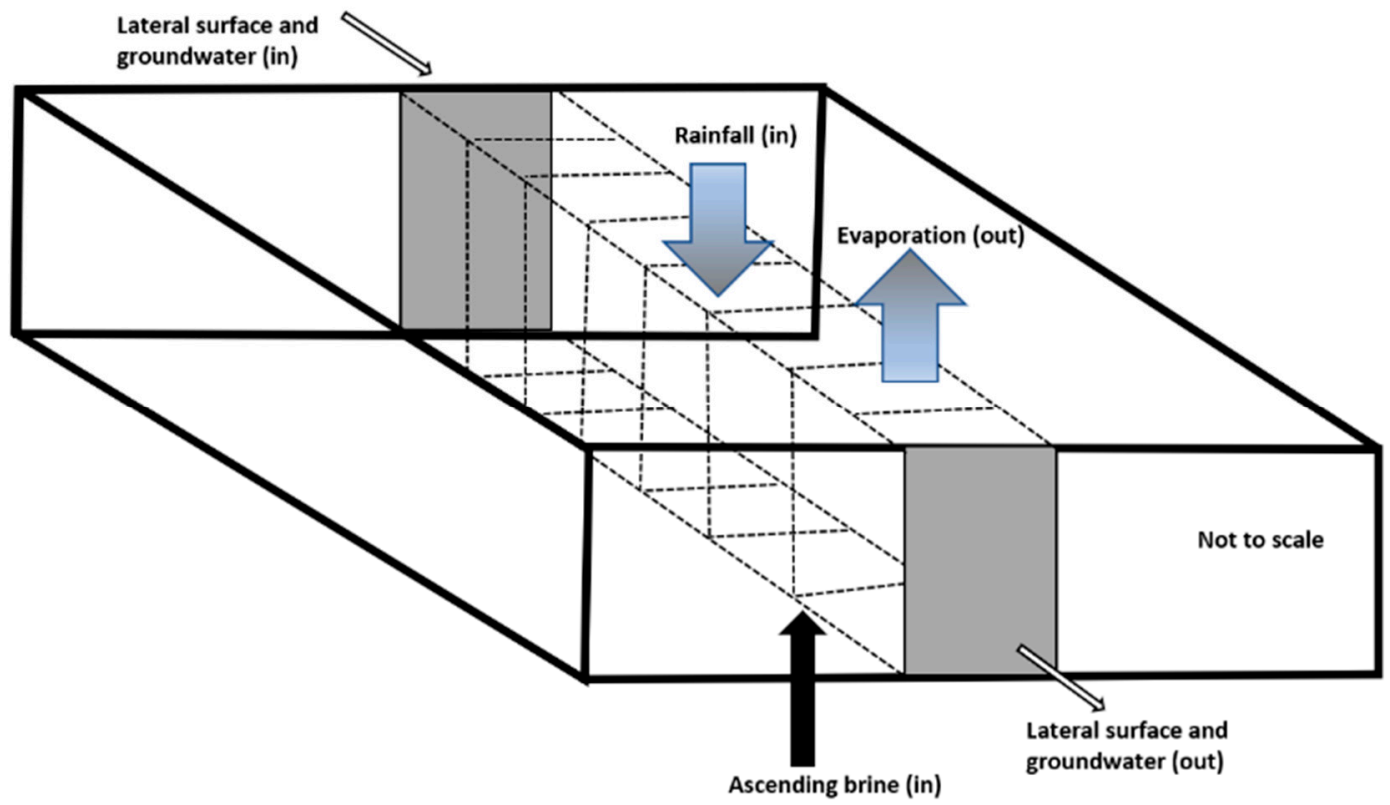

Figure 4. Water volume and mass balance in the sabkha Matti.

The inflow components to the SM include: (1) direct precipitation on the aquifer, (2) shallow groundwater entering the SM laterally from the mainland, and (3) upward leakage from the underlying regional aquifers. No substantial surface runoff has occurred to the sabkha through the duration of this study. However, field observations demonstrate that there must have been some recent overland flow in the last 100 years, as many of the surface features have a fluvial not aeolian expression and little of the sabkha is covered with dunes/sand sheets. For simplicity's sake and due to the absence of data, the surface runoff to and from the control volume is assumed to be negligible. Water may leave the sabkha by discharge laterally to the Arabian Gulf and by direct evaporation.

\subsubsection{Lateral Groundwater Fluxes}

B Darcy's law (Equation (1)) was used to estimate the lateral fluxes of groundwater into and out of the SM.

$$
\mathrm{q}=-\mathrm{K}(\mathrm{dh} / \mathrm{dl}),
$$

where $\mathrm{q}$ is the flux in dimensions of length per time $(\mathrm{L} / \mathrm{T}), \mathrm{K}$ is the hydraulic conductivity of the porous medium in dimensions of length per time $(\mathrm{L} / \mathrm{T})$, and $\mathrm{dh} / \mathrm{dl}$ is the gradient in the hydraulic head in the direction of flow in dimensions of length per length (dimensionless). In the SMF, the gradient is toward the coastline and the water table has a typical gradient of approximately $2 \mathrm{~m}$ in $10 \mathrm{~km}$ (Figure 1 ). To obtain horizontal hydraulic conductivity values $\left(\mathrm{K}_{\mathrm{h}}\right)$, slug tests were performed and evaluated on eight short-screened observation wells using the method of Hvorslev [17]. The lithology in these wells ranges from marly sands to clean sand facies, which makes them good representative samples of the fluvial and sabkha nature of the SMF. The slug test results give an arithmetic mean $\mathrm{K}_{\mathrm{h}}$ value of about $1.4 \mathrm{~m} / \mathrm{d}$ (Table S1, Supporting Information). From the gradient and $\mathrm{K}_{\mathrm{h}}$ values, the lateral groundwater flux in the SMF is about $0.2 \mathrm{~mm} / \mathrm{d}$.

\subsubsection{Upward Leakage}

The artesian hydraulic heads in the regional Hadrukh and Dam Formations, and upward hydraulic gradients across the Shuweihat and SM Formations (Table S2, Supporting Information), are consistent with the fact that regional groundwater is moving slowly upward into the base of the sabkha. From the hydrostatic data, an average upward hydraulic gradient of 0.14 was calculated from three separate pairs of multilevel wells. The hydraulic conductivity in this case is the vertical hydraulic conductivity 
$\left(\mathrm{K}_{\mathrm{v}}\right)$ of the least conductive layer underlying the sabkha. Measuring $\mathrm{K}_{\mathrm{v}}$ in situ is usually difficult, in that it must be measured either on cores or as a secondary parameter on a test for horizontal conductivity. However, it has been verified based on field data that a harmonic weighting of the horizontal conductivities can yield a reasonable estimate of the net vertical conductivity [14]. Slug tests were carried out at three observation wells, where the screens were installed within the aquitard underlying the sabkha. The obtained $K_{h}$ values from the three-slug test are $3 \times 10^{-4}, 4 \times 10^{-5}$, and $9 \times 10^{-6} \mathrm{~m} / \mathrm{d}$. Field observation suggests that this variation in the $\mathrm{K}_{\mathrm{h}}$ values is mainly due to the high heterogeneity in the aquitard layer, which is composed of a mixture of silty sands and well-compacted mudstones. These data reveal that there might be a significant level of uncertainty in the estimated $K_{v}$ for the aquitard. With this in mind, a harmonic weighting of the $K_{h}$ value was calculated to be about $2 \times 10^{-5} \mathrm{~m} / \mathrm{d}$, which is assumed to represent the net $\mathrm{K}_{\mathrm{v}}$ value for the confining layer underlying the sabkha. This value corresponds to clayey sandstones [18], consistent with the geological logs. Using Darcy's law, the mean upward leakage calculated with the above values of head gradient and $K_{\mathrm{v}}$ is approximately $3 \times 10^{-6} \mathrm{~m} / \mathrm{d}$ or about $1 \mathrm{~mm} / \mathrm{year}$. This estimate of the upward flux is a calculation of water flux multiplied by the solute concentration of the upwelling brines, providing a mass flux. This estimate of the upward flux is compared with the chemistry of the upwelling brines in the below section, and the results demonstrate that the estimates are consistent with the solute mass balance. These calculations over the 5000 years given for the age of the sabkha Matti Fm. demonstrate that the estimates are consistent with the origin of solute mass in the aquifer system. A relatively similar vertical water flux of approximately $4 \mathrm{~mm} / \mathrm{y}$ was reported from the coastal sabkha of $\mathrm{Abu}$ Dhabi, United Arab Emirates [14].

\subsubsection{Evaporation and Recharge}

The actual evaporation from the surface of the SMF was estimated to be $39 \pm 13 \mathrm{~mm} / \mathrm{y}$, based on a remote sensing technique [19]. The assumption that the SM is operating under a steady-state condition requires that the flux out by evaporation must equal the flux in by rainfall. To evaluate this assumption, the mean annual rainfall was taken over a fourteen-year period from three meteorological stations in the vicinity of the SM (Figure 1). The data range from $44.5 \mathrm{~mm}$ at the Al Ruwais station in the further northeast to $42.2 \mathrm{~mm}$ at the $\mathrm{Al}$ Gheweifat station in the northwest to $29 \mathrm{~mm}$ at the $\mathrm{Al}$ Jazeera station southeast of the SM [20]. This gives a mean annual rainfall of about $39 \mathrm{~mm} /$ year. In order to determine the amount of rainwater that infiltrated to the groundwater table, water tables were monitored in three designated wells during the summer, where no rainfall occurred, and one measurement was taken after a $13.3 \mathrm{~mm}$ rain event in March of 2017 (Table S3, Supporting Information). After the rain event, the rises in water levels were measured to be 35,30 , and $30 \mathrm{~mm}$. By multiplying these values with the porosity of 0.38 , the ratio of infiltrated water to the rain event suggests that between $86 \%-100 \%$ of the rainfall was accounted for at the water table. The highest recharge ratio to the water table was recorded in a well that was drilled adjacent to a solution collapse feature, which is very common in the area as a result of salt crust dissolution. Similar observations were reported from the coastal sabkha of Abu Dhabi, where more than $80 \%$ of the rainfall infiltrates to the water table [14]. The outcomes of the evaporation and recharge data provide further evidence of the steady-state nature of the sabkha system, where the water lost by evaporation is balanced by the mean annual recharge.

\subsection{Solute Budget}

The concentrations of major ionic constituents are plotted in the triangular plots, using the Geochemist's Workbench software (Figure 5). The triangular diagram is used to infer hydro-geochemical facies by showing the relative concentrations of different ions in the analyzed water samples [21]. What the data on the triangular plots show is that, regardless of the aquifer, all the water samples are of $\mathrm{Na}-\mathrm{Cl}$ water types and have similar ionic compositions. This similarity in the water types and ionic compositions among all groundwater samples suggests that the waters may have the same or similar origins. 


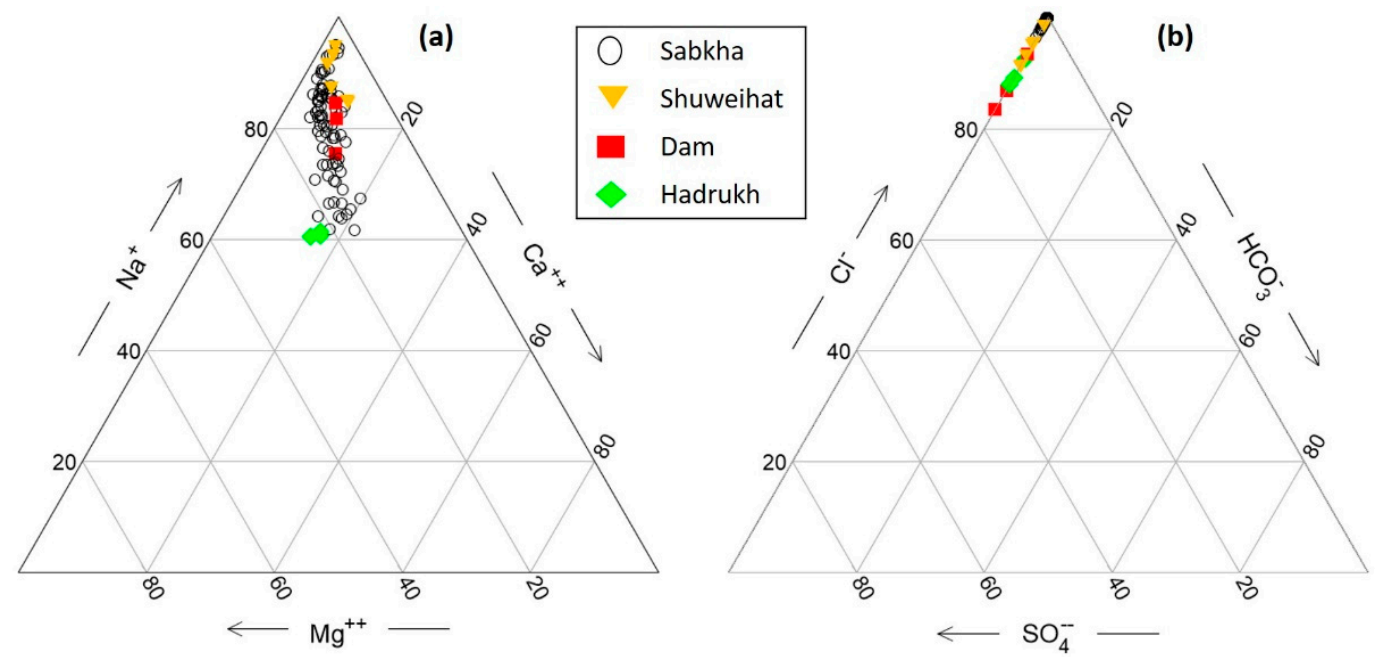

Figure 5. Triangular plots of (a) major cations and (b) major anions prepared from concentrations in equivalent units of water samples collected from different aquifers in the sabkha Matti area.

A solute budget was similarly developed around a volumetric cross section of the sabkha that is $20 \mathrm{~km}$ long, $1 \mathrm{~m}$ wide, and $5 \mathrm{~m}$ deep. The major ionic constituents and strontium isotope ratios in water samples collected from the Hadrukh, Dam, and Shuweihat formations resemble those ones that were obtained from the near-surface sabkha brine [4]. These data along with hydrostatic head measurements suggest a major source for the solutes in the SM to be associated with ascending brine from the underlying regional aquifers. Yet, solutes may also enter the SM with the surface-water transport, from atmospheric precipitation, be formed by the reaction of the water with the aquifer solids, enter the system by an eolian process, or form by reaction with the gasses. Solute may leave the system by being transported with the groundwater or surface flow, leave by diffusion, leave by mineral precipitation, leave by an eolian process, or leave as a gas phase. Solute concentrations are almost certainly transient, as will be shown below by their continuous input and relative lack of output.

The mean dissolved solids concentration results from the different geological formations at the SM are shown in Table 1. The components of the solute budget can be calculated from multiplying the mean dissolved solids concentrations, represented by the mean chloride concentrations, by the water budget [14]. By using the lateral water-inflow value of about 445 million L/year and a $\mathrm{Cl}$ input concentration value of $160 \mathrm{~g} / \mathrm{L}$, the lateral inflow of solutes from the upgradient of the sabkha is estimated to be about $70 \mathrm{~kg} /$ year. Similarly, a lateral water outflow value of approximately $1800 \mathrm{~L} /$ year multiplied by an outflow concentration of $\mathrm{Cl}$ of $200 \mathrm{~g} / \mathrm{L}$ results in an estimated $350 \mathrm{~kg} / \mathrm{year}$ of solute outflow. Likewise, the upward leakage value of around 22,170 L/year multiplied by a mean $\mathrm{Cl}$ concentration of $55 \mathrm{~g} / \mathrm{L}$ results in $1250 \mathrm{~kg} /$ year of upward leakage of solutes. It is assumed that the concentration increases over time by a combination of evaporation, mineral solution by recharge, and density-driven free convection that is circulating the solutes. It is also assumed that some salt is leaving the system through the land surface by deflation. A compilation of the component values of the water and solute budget is summarized in Table 2 . 
Table 1. Solute chemistry $(\mathrm{mg} / \mathrm{L})$ of the groundwater samples collected from different aquifers in the sabkha Matti area.

\begin{tabular}{cccccccc}
\hline Aquifer & $\mathbf{C a}$ & $\mathbf{K}$ & $\mathbf{M g}$ & $\mathbf{N a}$ & $\mathbf{C l}$ & $\mathbf{S O}_{4}$ & $\mathbf{S r}$ \\
\hline Hadrukh & 4800 & 1300 & 2600 & 35,000 & 69,500 & 2850 & 85 \\
Hadrukh & 4500 & 1300 & 2500 & 34,000 & 67,600 & 2950 & 85 \\
Dam & 2160 & 581 & 1370 & 27,100 & 43,909 & 3914 & 46 \\
Shuweihat & 2840 & 522 & 1150 & 31,200 & 54,927 & 3350 & 75 \\
Shuweihat & 2800 & 541 & 1090 & 29,500 & 45,567 & 3083 & 54 \\
Sabkha $(n=119)$ & 10,894 & 3438 & 7854 & 72,406 & 170,654 & 1739 & 254 \\
\hline
\end{tabular}

Table 2. Components of the water and solute budgets calculated in this study, based on the control volume of the sabkha that is $20 \mathrm{~km}$ long, $1 \mathrm{~m}$ wide, and $5 \mathrm{~m}$ deep.

\begin{tabular}{ccc}
\hline Budget Component Flux & Volumetric Water Flux $\mathbf{~ ( m ~}^{\mathbf{3}} /$ year) & Total Solute (kg/year) \\
\hline Lateral flux in & 1 & 70 \\
Lateral flux out & 2 & 350 \\
Upward leakage & 20 & 1250 \\
Evaporation & 780 & 0 \\
Rainfall & $780-670$ & $<1$ \\
Increase in storage & 0 & 970 \\
\hline
\end{tabular}

\section{Discussion}

The lateral groundwater flux in the SMF is calculated to be $0.2 \mathrm{~mm} / \mathrm{d}$. This flux value can be converted to a seepage velocity by dividing the flux by the effective porosity. Based on grain-size distribution analyses [22], several laboratory analyses of the sand from the SMF yield a consistent effective porosity of approximately 0.38 . Given this value of porosity, the lateral seepage velocity through the SMF is estimated to be about $0.5 \mathrm{~mm} / \mathrm{d}$. The lateral flux out of the SMF was calculated downgradient of the sabkha. In this area, the hydraulic gradient is about $7 \mathrm{~m}$ in $10 \mathrm{~km}(0.0007)$. Accordingly, the lateral groundwater flux out of SM is calculated to be about $1 \mathrm{~mm} / \mathrm{d}$. For the purposes of comparing the magnitude of the different components of the hydrologic budget, the fluxes are multiplied by the width $(1 \mathrm{~m})$ and thickness $(5 \mathrm{~m})$ of the sabkha to obtain lateral volumetric fluxes. The fluxes in and out of the sabkha obtain lateral volumetric flux values of about $1 \mathrm{~m}^{3} /$ year and $2 \mathrm{~m}^{3} /$ year, respectively (Table 2). The average residence time for the lateral groundwater flux to be transmitted from the proximal end to the distal end at the discharge zone is calculated by dividing one half the length of the sabkha $(150 \mathrm{~km})$ by the seepage velocity. Accordingly, the average residence time of groundwater is approximately 416,000 years. Given that the age of the SM is approximately 8000 to 5000 years old, it is concluded that lateral influx of groundwater has not contributed significantly to the current volume of water and solutes in the sabkha. The calculated upward flux is multiplied by the width $(1 \mathrm{~m})$ and length $(20,000 \mathrm{~m})$ of the section to obtain a total upward volumetric flux of about $20 \mathrm{~m}^{3} /$ year. This value is significantly larger than the horizontal flux, of $1 \mathrm{~m}^{3} /$ year. These calculations suggest that the upward leakage from the underlying regional aquifers provides an important source of groundwater entering the sabkha. The pore volume of brine that might fill the SMF over its life span was calculated by multiplying the mean upward flux by the porosity and the age of the sabkha. Based on this, an approximately three pore volumes should have filled the 5-m-thick section of the SMF over its saturated life span of 5000 years. Hypothetically, the ratios of the average concentrations of conservative solutes from the underlying regional aquifers to those in the sabkha should be equal to the number of pore volumes that have entered the sabkha. Such ratios are shown in Figure 6. Field observations suggest a relatively conservative nature for magnesium and potassium, as no significant precipitations of both minerals were observed throughout the study area. Accordingly, $\mathrm{K}$ and $\mathrm{Mg}$ were assumed to be the most conservative ions in this geological setting, and their ratios indicate that about three pore volumes have entered the sabkha. This result reveals that the solute and 
water budget estimates of three pore volumes are in complete agreement. However, minerals that have significantly precipitated on the sabkha surface show lower ratios. This includes sodium and chloride, which precipitate as halite, calcium, and sulfate precipitate as anhydrite. Thus, the solute budget is totally in line with the hydrologic budget and the age of the SM. Moreover, the actual evaporation from the surface of the SMF of $39 \mathrm{~mm} / \mathrm{y}$ is multiplied by the section width of $1 \mathrm{~m}$ and the section length of $20,000 \mathrm{~m}$ to give a volumetric flux out of about $780 \mathrm{~m}^{3} /$ year. As the system is assumed to operate under a steady-state condition, the water lost by evaporation is balanced by the mean annual recharge that is calculated to be between 670 and $780 \mathrm{~m}^{3} /$ year. These data reveal that evaporation and recharge on the sabkha are the dominant components, whereas the lateral and upwelling groundwater components are minor. Note, however, that the solute mass is dominated by upwelling water. The water mass balance in the SM is illustrated in Figure 4.

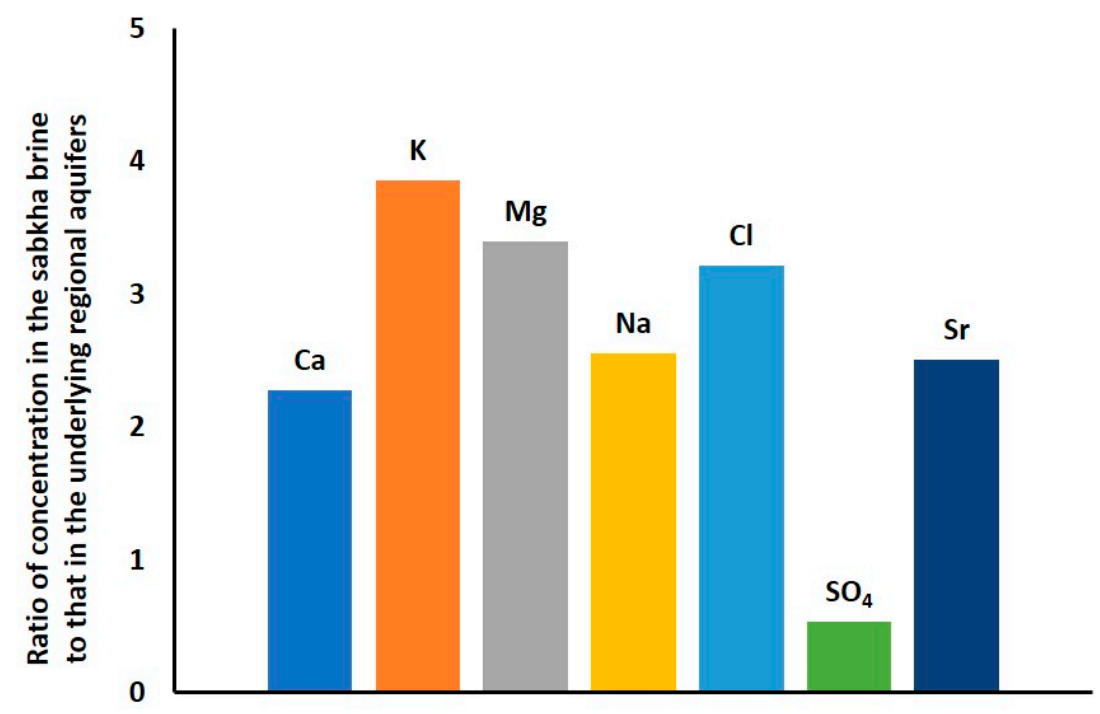

Figure 6. Ratios of the major element concentrations for the upwelling regional brine relative to the brine in the sabkha Matti.

\section{Conclusions}

A hydrologic budget of the sabkha Matti was constructed as an approach to better understand the regional groundwater systems of the large drainage area $>250,000 \mathrm{~km}^{2}$ in the Rub' al Khali structural basin. The data reveal that the hydrologic budget for the sabkha Matti system is operating under a steady-state condition, where all of the inflows to the sabkha equal all of the outflows. Steady-state estimates within a rectilinear control volume of the sabkha indicate that about $1 \mathrm{~m}^{3} /$ year of water enters by lateral groundwater flow, $2 \mathrm{~m}^{3} /$ year of water exits by lateral groundwater flow, $20 \mathrm{~m}^{3} /$ year enters by upward leakage, $780 \mathrm{~m}^{3} /$ year enters by recharge from rainfall, and $780 \mathrm{~m}^{3} /$ year is lost by evaporation. Therefore, a quantification of the components to the water budget suggests that evaporation and rainfall are the dominant components, whereas the lateral and upwelling groundwater components are minor. In contrast, the analysis of the solute budget shows that the dominant source of solutes is upward leakage from the underlying regional aquifers, consistent with the ascending brine model proposed by $[1,3,4,14]$. For instance, the calculation of the solute budget shows that about $95 \%$ of the solutes are derived from ascending continental brines, whereas only minor amounts are derived from rainfall and from groundwater entering from up-gradient areas. Therefore, this study shows that the water and solutes in the sabkha Matti are from different sources. These data also show that about three pore volumes of brine may have leaked upward into the control volume of the sabkha since the time it was first formed about 5000 years ago. Over time, the solute concentrations have increased by a combination of evaporation, mineral solution by recharge, and density-driven free-convection that is circulating the solutes within the sabkha. The proposed conceptual model of the hydrology for sabkha 
Matti is assumed to apply to the rest of the inland sabkhas of the Arabia Peninsula and to many ancient environments of deposition observed in the geologic record.

Supplementary Materials: The following are available online at http://www.mdpi.com/2306-5338/7/4/94/s1: Table S1: Well information and estimated horizontal hydraulic conductivities for the sabkha Matti Formation, obtained from slug tests. Table S2: Water level measurements from the multi-level wells at the sabkha Matti, confirming the potential of upward leakage from the regional Hadrukh and Dam Formations into the sabkha. Water levels are in meters above sea level. Table S3: Water level measurement data to determine the ratio of infiltrated rainwater to the sabkha Matti Formation.

Author Contributions: Conceptualization, W.S., O.S.-S., and W.W.; methodology, W.S., O.S.-S., validation, W.S., O.S.-S., A.U., W.W., B.P.; formal analysis, W.S., O.S.-S.; investigation, W.S.; resources, W.S., O.S.-S., A.U., W.W., B.P.; data curation, W.S.; writing-original draft preparation, W.S.; writing-review and editing, O.S.-S., A.U., W.W., B.P.; visualization, W.S.; O.S.-S. and W.W.; supervision, O.S.-S., B.P., A.U.; project administration, W.S.; funding acquisition, W.S. All authors have read and agreed to the published version of the manuscript.

Funding: This research was funded by the SAUDI ARAMCO OIL COMPANY.

Acknowledgments: The author would also like to thank the Environmental Agency Abu Dhabi (EAD) for granting access to the field sites in the United Arab Emirates and for the information derived from its website, which was used in the preparation of this work.

Conflicts of Interest: The authors declare no conflict of interest.

\section{References}

1. Wood, W.W.; Sanford, W.; Al Habshi, A.R.S. Source of solutes to the coastal sabkha of Abu Dhabi. GSA Bull. 2002, 114, 259-268. [CrossRef]

2. Robinson, B.W.; Gunatilaka, A. Stable isotope studies and the hydrological regime of sabkhas in southern Kuwait, Arabian Gulf. Sediment. Geol. 1991, 73, 141-159. [CrossRef]

3. Yechieli, Y.; Wood, W.W. Hydrogeologic processes in saline systems: Playas, sabkhas, and saline lakes. Earth Sci. Rev. 2002, 58, 343-365. [CrossRef]

4. Saeed, W.; Shouakar-Stash, O.; Unger, A.; Wood, W.W.; Parker, B. Chemical evolution of an inland Sabkha: A case study from Sabkha Matti, Saudi Arabia. Hydrogeol. J.. under review.

5. Wender, L.E.; Bryant, J.W.; Dickens, M.F.; Neville, A.S.; Al-Moqbel, A.M. Paleozoic (pre-khuff) hydrocarbon geology of the Ghawar area, eastern Saudi Arabia. Geoarabia 1998, 3, $273-302$.

6. Goodall, T.M. The Geology and Geomorphology of the Sabkhat Matti Region (United Arab Emirates): A Modern Analogue for Ancient Desert Sediments from North-West Europe. Ph.D. Thesis, University of Aberdeen, Aberdeen, Scotland, 1995.

7. Nairn, A.; Alsharhan, A. Sedimentary Basins and Petroleum Geology of the Middle East, 1st ed.; Elsevier: Amsterdam, The Netherlands, 1997; pp. 87-465.

8. Martin, A.Z. Late Permian to Holocene Paleofacies evolution of the Arabian plate and its hydrocarbon occurrences. Geoarabia 2001, 6, 445-504.

9. Powers, R.; Ramirez, L.; Redmond, C.; Elberg, E.L., Jr. Geology of the Arabian Peninsula—Sedimentary Geology of Saudi Arabia; Professional paper 560-D; USGS: Reston, VA, USA, 1996.

10. Alsharhan, A.; Rizk, Z.; Nairn, A.E.M.; Bakhit, D.; Alhajari, S. Hydrogeology of an Arid Region: The Arabian Gulf and Adjoining Areas, 1st ed.; Elsevier: Amsterdam, The Netherlands, 2001; pp. 55-77.

11. Bristow, C. Aeolian and Sabkha Sediments in the Miocene Shuwaihat Formation, Emirate of Abu Dhabi, United Arab Emirates. In Fossil Vertebrates of Arabia, 1st ed.; Whybrow, P.J., Hill, A., Eds.; Yale University Press: London, UK, 1999; pp. 50-60.

12. Orang, K.; Motamedi, H.; Azadikhah, A.; Royatvand, M. Structural framework and tectono-stratigraphic evolution of the eastern Persian Gulf, offshore Iran. Mar. Pet. Geol. 2018, 91, 89-107. [CrossRef]

13. Alsharhan, A.; Kendall, C.G.S.C. Holocene coastal carbonates and evaporites of the southern Arabian Gulf and their ancient analogues. Earth Sci. Rev. 2003, 61, 191-243. [CrossRef]

14. Sanford, W.E.; Wood, W.W. Hydrology of the coastal sabkhas of Abu Dhabi, United Arab Emirates. Hydrogeol. J. 2001, 9, 358-366. [CrossRef]

15. Wood, W.W.; Böhlke, J. Density-Driven Free-Convection Model for Isotopically Fractionated Geogenic Nitrate in Sabkha Brine. Ground Water 2016, 55, 199-207. [CrossRef] [PubMed] 
16. US EPA. Determination of Inorganic Anions in Drinking Water by Ion Chromatography; Method 300.1; US EPA: Cincinnati, OH, USA, 1997.

17. Hvorslev, M.J. Time Lag and Soil Permeability in Groundwater Observations; Waterways Experiment Station, US Army: Vicksburg, MS, USA, 1951.

18. Domenico, P.A.; Schwartz, F.W. Physical and Chemical Hydrogeology, 2nd ed.; Wiley: New York, NY, USA, 1997.

19. Schulz, S.; Horovitz, M.; Rausch, R.; Michelsen, N.; Mallast, U.; Köhne, M.; Siebert, C.H.; Schüth, C.; Al-Saud, M.; Merz, R. Groundwater evaporation from salt pans: Examples from the eastern Arabian Peninsula. J. Hydrol. 2015, 531, 792-801. [CrossRef]

20. NCMS. National Center for Meteorology and Seismology, Abu Dhabi, United Arab Emirates. 2018. Available online: http://www.ncms.ae/en/details.html?id=1525\&lid=3300 (accessed on 8 October 2020).

21. Fuoco, I.; Figoli, A.; Criscuoli, A.; Brozzo, G.; De Rosa, R.; Gabriele, B.; Apollaro, C. Geochemical modeling of chromium release in natural waters and treatment by RO/NF membrane processes. Chemosphere 2020, 254. [CrossRef] [PubMed]

22. Vuković, M.; Soro, A. Determination of Hydraulic Conductivity of Porous Media from Grain-Size Composition; Water Resources Publications: Littleton, CO, USA, 1992.

Publisher's Note: MDPI stays neutral with regard to jurisdictional claims in published maps and institutional affiliations.

(C) 2020 by the authors. Licensee MDPI, Basel, Switzerland. This article is an open access article distributed under the terms and conditions of the Creative Commons Attribution (CC BY) license (http://creativecommons.org/licenses/by/4.0/). 